UDC $576.54: 578.23: 616-006.04$

\title{
Mouse embryonic fibroblasts expressing IFN $\beta$ or IL-21 inhibit proliferation of melanoma cells in vitro
}

\author{
I. N. Vagyna, O. A. Zaharuk, L. I. Strokovska, Y. V. Vagyn, V. I. Kashuba \\ Institute of Molecular Biology and Genetics, NAS of Ukraine \\ 150, Akademika Zabolotnoho Str., Kyiv, Ukraine, 03680 \\ ira_vag@ukr.net
}

\begin{abstract}
Aim. To study an influence of mouse embryonic fibroblasts $(\mathrm{C} 57 \mathrm{Fb})$ transduced with baculovirus vectors (BVs), encoding genes for murine Ifn- $\beta$ or human $I L 21$, on survival and proliferation of the malignant mouse melanoma cells (B16) in vitro. Methods. Transduction of cells, construction of BVs, RNA isolation, quantitative PCR. Results. We have shown that the normal C57Fb and B16 tumor cells are sensitive to the anti-proliferative effect of IFN $\beta$. Rapidly proliferating B16 cells were the most sensitive. BV ensured a stable expression of If $n \beta$ mRNA for 5 days in $\mathrm{C} 57 \mathrm{Fb} / \mathrm{IFN} \beta$ cells. The growth of B16 cells was suppressed upon co-cultivation with $\mathrm{C} 57 \mathrm{Fb} / \mathrm{IFN} \beta$ or $\mathrm{C} 57 \mathrm{Fb} / \mathrm{IL} 21$ cells. Conclusions. IFN $\beta$ and IL-21 synthesized by the mouse embryonic fibroblasts transduced with BVs carrying the Ifn $\beta$ or $I L-21$ genes inhibited proliferation of B16 melanoma cells in vitro.
\end{abstract}

Keywords: mouse embryonic fibroblasts, melanoma cells, interferon $\beta$ (IFN $\beta$ ), interleukin-21 (IL-21), baculovirus vector, cell transduction.

\section{Introduction}

One of the most promising trends in anti-tumor therapy is the use of genetically modified cells. Over the past several years, genetically engineered mesenchymal stem cells (MSCs) have been extensively investigated as a novel vehicle for the cancer gene therapy. They are weakly immunogenic and exhibit a remarkable migratory property towards tumors. The adult human fibroblasts demonstrate similar properties [1-5]. Nowadays a possible application of embryonic and fetal fibroblasts, in particular mouse embryonic fibroblasts (MEFs), in the regenerative cell therapy and in model systems draw more and more attention. It has been shown that the majority of these cells express antigens of the major histocompatibility complex (MHC-I and MHC-II) at the low levels. Embryonic and fetal organs contain, along with differentiated cells, stem and acti- vated (blast) cells, endowed with a high potential of proliferation and secreting a unique set of cytokines and growth factors in a recipient after grafting [6, 7]. MEFs actively proliferated in culture until passage 12 ; they are widely used as a feeder layer to support the growth of embryonic stem cells and also they are involved in regulating the organ development, wound and burn healing, inflammation and fibrosis [8, 9]. Several reports have conclusively shown that MEFs are similar to MSCs phenotypically, genotypically and functionally $[10,11]$. Both MEFs and MSCs are defined as plastic adherent, clonogenic, multipotent fibroblast like the cells that have similar morphological appearance, identical cell surface markers and the ability to undergo mesoderm-type cell differentiation into osteocytes, adipocytes and chondrocytes [11-13]. Additionally, MEFs expressed the markers of embryonic stem cells [11]. These unique features make them an at-

(C) 2016 I. N. Vagyna et al.; Published by the Institute of Molecular Biology and Genetics, NAS of Ukraine on behalf of Biopolymers and Cell.

This is an Open Access article distributed under the terms of the Creative Commons Attribution License (http://creativecommons.org/licenses/by/4.0/),

which permits unrestricted reuse, distribution, and reproduction in any medium, provided the original work is properly cited 
tractive model for the delivery of therapeutic genes directly into the tumor microenvironment.

In the present work we have used interferon $\beta$ (IFN $\beta$ ) and interleukin-21 (IL-21) as the anti-tumor agents. It is known that IFN $\beta$ promotes apoptosis, exhibits the anti-proliferative effect on tumor cells, suppresses the angiogenesis in tumor tissues, reduces an ability of tumor to metastasize, and shows the immunomodulatory effects and anti-viral activity $[14,15]$. However, the clinical application of IFN $\beta$ had been limited by its severe toxicity associated with the excess protein distributing freely throughout the body upon systemic administration. Due to its short drug half-life and insufficient delivery to the target tumor cells, a systemic administration of IFN $\beta$ has shown a limited response to the initial therapy for most solid tumors [16]. Transduced stem cells can be used as a vehicle to deliver IFN $\beta$ or other cytokines into the tumor microenvironment reducing toxicity and increasing the local concentration of these therapeutic products at the tumor sites. Earlier, some model experiments demonstrated the effectiveness of this approach [16-19]. Interleukin-21 (IL-21) is a cytokine with broad pleiotropic actions including the regulation of development, differentiation and function of lymphoid and myeloid cells. The basic mechanism, which is associated with the antitumor activity of IL-21, is the activation of different subsets of killer cells [20, 21]. The studies using mouse tumour models in vivo as well as clinical trials in patients with advanced solid tumours have demonstrated that IL-21 can function as a potent antitumour agent [22, 23]. Human and murine IL-21 and IL-21 receptors show approximately $60 \%$ overall amino acid sequence homology with significant conservation in the regions of cytokine-receptor interaction, and to a large extent the function of IL-21 has been shown to be similar in mouse and human, although several discrepancies have also been described [21]. We used baculoviral vectors (BVs), derived from an insect virus, for the gene delivery into MEFs. This insect DNA virus has the ability to enter mammalian cells without replicating or causing toxicity to the transduced cell [24]. Previously we have demonstrated efficacy of the baculoviruses for such task [25].

In the present study we investigated the influence of MEFs $(\mathrm{C} 57 \mathrm{Fb})$ transduced with recombinant baculoviruses, bearing the mouse Ifn $\beta$ or human $I L-21$ genes on the survival and proliferation of mouse melanoma B16 malignant cells in vitro.

\section{Materials and Methods}

\section{Cell lines}

Cells of mouse melanoma B16 were obtained from the Bank of Cell Lines of R. E. Kavetsky Institute of Experimental pathology, oncology and radiobiology, NAS of Ukraine (IEPOR NASU). Mouse embryonic fibroblasts were isolated by enzymatic disaggregation of the soft tissue of 13.5 day old C57BL/6j mouse embryos [26]. Primary cells were passaged 2-3 times. All cells were cultured in DMEM medium (Sigma) supplemented with $10 \%$ fetal bovine serum FBS (Sigma), $100 \mathrm{U} / \mathrm{ml}$ penicillin and $100 \mu \mathrm{g} /$ $\mathrm{ml}$ streptomycin at $37{ }^{\circ} \mathrm{C}$ in a $\mathrm{CO}_{2}$ incubator. Monolayer culture of insect cell line $\mathrm{Sf} 21$ was grown in TC-100 medium (Sigma) supplemented with $10 \% \mathrm{FBS}$ at $28{ }^{\circ} \mathrm{C}$.

\section{Baculovirus vectors ( $B V S$ ) and $M E F$ transduction}

BVs were obtained from the Autographa californica Multiple NucleoPolyHedrovirus (AcMNPV), using the Bac-to-Bac expression system (Invitrogen). The following BVs were created: Ac-M-IFN, containing the murine $I f n \beta$ gene under regulation of promoter of chicken $\beta$-actine in the CAG cassette; Ac-IFN-GFP, containing two genes: reporter GFP under the CMV promoter and the murine Ifn $\beta$ gene in the CAG cassette; and also Ac-CMV-IL21 containing the human interleukin $I L-21$ gene under the CMV promoter. As controls, the following BVs were used: Ac-M-GFP; Ac-M-S1 8 carrying a gene, encoding the mitochondrial ribosomal protein S18-2; and AcFastMam that was designed on the base pFastBac plasmid with the CAG cassette [27]. The virus was concentrated by 
centrifugation at $100000 \mathrm{~g}$. The titer of viruses preparations was $2-4 \times 10^{8} \mathrm{pfu} / \mathrm{ml}$. Transduction was performed as desribed previously [28]. C57Fb cells were incubated with recombinant BVs at a concentration of 200 moi (multiplicity of infection = pfu per cell) for 4 hours at $28{ }^{\circ} \mathrm{C}$ in phosphate buffered saline (PBS), followed by addition of $1.5 \mathrm{ml}$ DMEM medium and culturing for 16 hours at $37^{\circ} \mathrm{C}$. At the end of the incubation period, the virus solution was discarded, cells were washed with PBS and $2 \mathrm{ml}$ DMEM medium containing $10 \%$ FBS was added.

\section{Analysis of cell proliferation}

B16 melanoma cells were seeded on 6-well plates at a concentration of $2 \times 10^{5}$ cells $/$ well and cultured together with $\mathrm{C} 57 \mathrm{Fb}$ cells transduced with BVs carrying the murine Ifn $\beta$ or human $I L-21$ gene at a concentration of $2 \times 10^{4}$ cells/well. In the control experiments, cells were seeded in the same amounts and ratios (1:10). As a control, we used the following variants of co-culturing cells: C57Fb: B16; C57Fb/GFP: B16; $\mathrm{C} 57 \mathrm{Fb} / \mathrm{S} 18$ : B16; $\mathrm{C} 57 \mathrm{Fb} /$ FastMam: B16. Also cells $\mathrm{C} 57 \mathrm{Fb}$ and $\mathrm{B} 16$ were transduced with the above BVs cultured alone $\left(2 \times 10^{5}\right.$ cells/well). And "pure" control - cells B16 and C57Fb cultured alone (not transduced) at a concentration of $2 \times 10^{5}$ cells $/$ well.

In all experiments, the cells were cultured for 5 days at the standard conditions without replacement of the culture medium. Cells were removed from the culture plates by the trypsin EDTA solution and re-suspended in PBS supplemented with serum (10\% FBS). The total cell number was then calculated. All experiments were performed in triplicate. The results are presented as the relative number of cells (in \% of the cell number in controls, see [16] for description).

\section{Assessment of the Ifn $\beta$ gene expression}

To monitor the kinetics of Ifn $\beta$ gene expression in transduced MEFs, the samples were collected at 0 , $24,48,72,96$, and 120 hours after transduction. As the controls the $\mathrm{C} 57 \mathrm{Fb}$ intact cells and $\mathrm{C} 57 \mathrm{Fb}$ cells transduced with AcFastMam at 0 and 24 hours were used.

\section{$R N A$ isolation and $c D N A$ synthesis}

RNA was isolated, using the RNA isolation kit (Fermentas/Thermo Fisher Scientific), according to the manufacturer's protocol. RNA concentration was measured, using a Nanodrop spectrophotometer (Thermo Fisher Scientific). The RNA was treated with DNase (Fermentas/ Thermo Fisher Scientific), and $1 \mu \mathrm{g}$ of RNA was applied in cDNA synthesis, using oligo-dT primer and cDNA synthesis kit (Fermentas). $2 \mu 1$ of the synthesized cDNA was used for q-PCR.

\section{Real-Time q-PCR}

The relative expression level of the gene $\operatorname{Ifn} \beta$ was assessed by q-PCR, using SYBR Green (Maxima SYBR qPCR Master Mix/Thermo Fisher Scientific) on a Real-Time thermocycler (CFX96 Real-time System C1000 Thermal Cycler / BIO-RAD). The $T B P$ was used as the reference gene. The following primers were used: TbpF1 5'-CCCCACAACTCTT CCATTCT-3'; TbpR1 5'-GCAGGAGTGATAGGG GTGAT-3'; Ifn-bF 5'-CCCTATGGAGATGACGG AGA-3'; Ifn-bR5'-CAGTCTGGAGAAATTGT-3'. Amplification parameters were: $50{ }^{\circ} \mathrm{C}-20 \mathrm{~min}$, $95^{\circ} \mathrm{C}-10 \mathrm{~min},\left(94^{\circ} \mathrm{C}-25 \mathrm{~s}, 60^{\circ} \mathrm{C}-25 \mathrm{~s}, 72^{\circ} \mathrm{C}-\right.$ 25 s) for 40 cycles, and $72{ }^{\circ} \mathrm{C}-2 \mathrm{~min}$.

\section{Statistical analysis}

Statistical analysis was performed using the Student's t-test.

\section{Results and Discussion}

\section{Effect of MEF (C57Fb) and tumor B16 cells} transduced with $B V s$, on the proliferation of melanoma cells $B 16$ in vitro

To examine a possible anti-proliferative effect of the $\mathrm{C} 57 \mathrm{Fb}$ cells transduced with the BVs carrying the Ifn $\beta$ or $I L-21$ genes, these cells were co-cultured with the malignant B16 cells in vitro. We have found that proliferation of the B16 cells was inhibited by the $\mathrm{C} 57 \mathrm{Fb}$ transduced $\mathrm{BVs}$ with gene Ifn $\beta$ (Fig. 1, columns 6,7 ) in comparison with the controls (columns 1-5). The amount of B16 melanoma cells in 
the control on 5 th day of culturing $-6 \times 10^{6}$ cells/well was taken for $100 \%$. The relative number of the B16 cells co-cultured with $\mathrm{C} 57 \mathrm{Fb} / \mathrm{IFN} \beta$ or $\mathrm{C} 57 \mathrm{Fb} / \mathrm{IFN} \beta$ GFP cells $(4.5 \pm 2.7 \%$ and $2.8 \pm 1.2 \%$, respectively) was decreased significantly in comparison with all the controls, and these differences were statistically significant $(p<0.001)$. The number of B16 cells cultured together with $\mathrm{C} 57 \mathrm{Fb} / \mathrm{FastMam}$ cells (Fig. 1, column 5) was significantly lower compared to the number of B16 cell cultured alone ( $<<0.01$ ). Moreover, the significant reduction in the number of these cells was observed $(\mathrm{p}<0.05)$ when compared with the control mixtures of cells (Fig. 1, columns 2-4). It was shown earlier that baculovirus transduction could activate the TLR3 (toll-like receptor) pathway in MSCs and triggered secretion of various cytokines, including IFN $\alpha$ and IFN $\beta$, although a level of their secretion was low $[29,30]$. Nevertheless, the properties of MEFs and their production of endogenous IFN in response to transduction of BVs were not investigated earlier. We also found that in all control mixtures of $\mathrm{B} 16$ cells with $\mathrm{C} 57 \mathrm{Fb}$ the number of B16 cells was statistically significantly reduced $(p<0.05)$ compared with the growth of B16

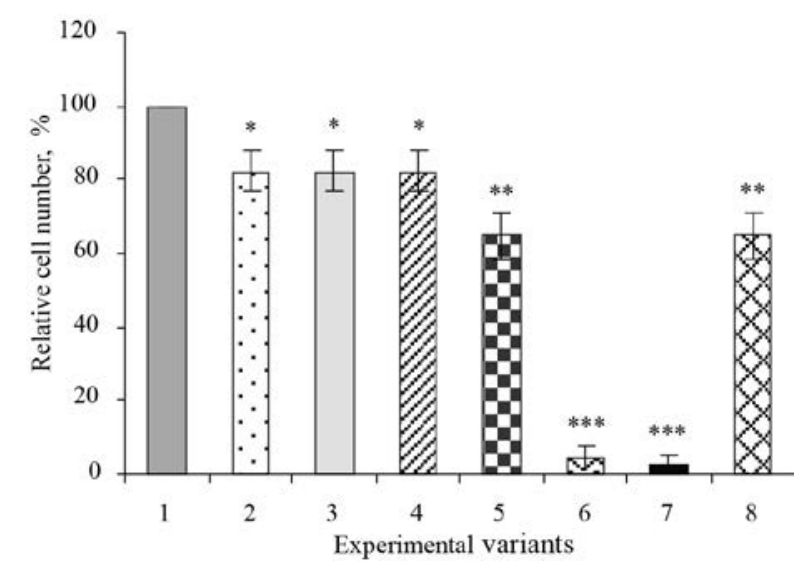

Fig. 1. Effect of co-culturing of embryonic fibroblasts $\mathrm{C} 57 \mathrm{Fb}$ expressing IFN $\beta$ or IL-21, on the proliferation of B16 cells in vitro. 1 - "pure" control B16 cells; control mixtures of cells: 2 C57Fb: B16; 3 - C57Fb/GFP: B16; 4 - C57Fb/S18: B16; 5 $\mathrm{C} 57 \mathrm{Fb} /$ FastMam: B16; cell mixtures in experiment: 6 - $\mathrm{C} 57 \mathrm{Fb}$ / IFN $\beta$ : B16; 7 - C57Fb/IFN $\beta$-GFP: B16; 8 - C57Fb/IL21: B16. The differences are significant at $* \mathrm{p}<0,05 ; * * \mathrm{p}<0,01 ; * * * \mathrm{p}<$ 0,001 compared to the control. cells alone. Therefore, modeling in vitro interaction of heterologous cells in tumor - melanoma cells (B16) and fibroblasts (MEFs), we have shown that IFN $\beta$, synthesized by $\mathrm{C} 57 \mathrm{Fb} / \mathrm{IFN} \beta$ or $\mathrm{C} 57 \mathrm{Fb} / \mathrm{IFN} \beta$ GFP cells, inhibits the proliferation of tumor B16 cells. The presented results are consistent with the earlier reports $[16,31,32]$. Notably, in the referred here studies MSCs used showed a stimulating effect on the tumor cells (including melanoma cells) growth when co-cultured in vitro. Recently, there are increasing evidences that MSCs exhibit the promotion or inhibition of the tumor growth and the invasion through direct or indirect interaction with the tumor cells [33]. As discussed above, the $\mathrm{C} 57 \mathrm{Fb}$ cells exerted an inhibitory effect on the B16 tumor cell growth. This fact also indicates the perspective of using MEFs as a vector in the experimental mouse models of melanoma in vivo.

When B16 cells were co-cultured with $\mathrm{C} 57 \mathrm{Fb} /$ IL21 cells (Fig. 1, column 8) a significant decrease in the number of B16 cells was observed, compared with a "pure" control $(\mathrm{p}<0.01)$ and the control mixtures of cells $(p<0.05)$. Although IL-21 was originally described as an important regulator of T, B and NK cells, which play key roles in antitumoral immunity, our results have shown that IL21 inhibits proliferation of malignant melanoma cells upon cocultivating with $\mathrm{C} 57 \mathrm{Fb} / \mathrm{IL} 21$ cells in vitro. Further studies are needed to clarify, whether the melanoma cells are a direct target of IL-21 or this cytokine acts indirectly by activating intracellular processes in fibroblasts.

Since the tumor cells interact with each other and with the surrounding normal cells, we considered interesting to model the interaction between homologous cells in tumor, using B16 cells and B16, transduced with BVs carrying the Ifn $\beta$ or $I L-21$ genes. A significant decrease in the number of tumor cells (Fig. 2, columns 5-6) occurred when B16 cells were co-cultured with B16, transduced with BV containing the Ifn $\beta$ gene, in comparison with the controls (columns 1-4): $21.7 \%$ (B16/IFN $\beta$ :B16) and 30.3\% (B16/IFN $\beta-G F P: B 16)$. The observed difference was statistically significant $(\mathrm{p}<0.001)$. 


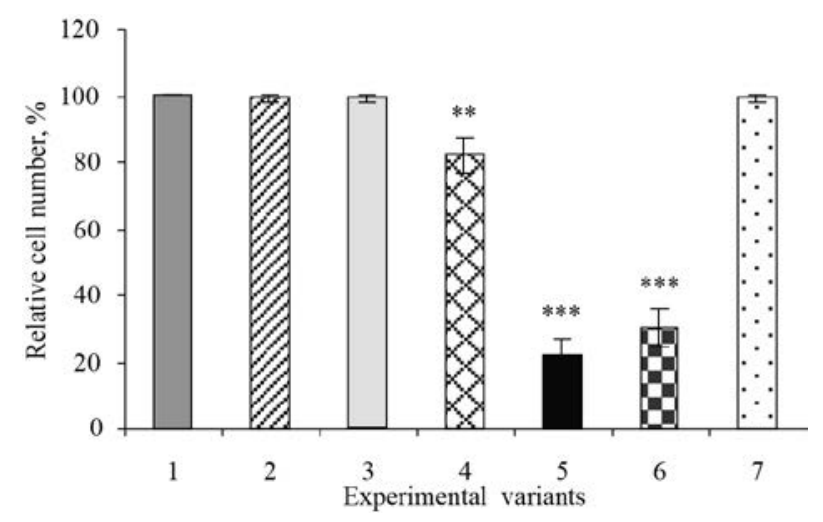

Fig. 2. Effect of co-culture of melanoma B16 cells transduced with $\mathrm{BVs}$ and non transduced $\mathrm{B} 16$ cells in vitro. $1 .-\mathrm{B} 16$ control cells; 2. - B16/GFP: B16; 3. - B16/S18: B16; 4. - B16/Fast-

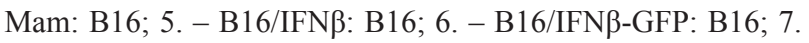
$-\mathrm{B} 16 / \mathrm{IL} 21: \mathrm{B} 16$. The differences are significant at $* * \mathrm{p}<0.01$; $* * * \mathrm{p}<0.001$ compared to the control.

Thus, when co-cultured the homologous cells (B16/IFN $\beta: B 16$, B16/IFN $\beta-G F P: B 16)$ or the heterologous (C57Fb/IFN $\beta$ :B16, C57Fb/IFN $\beta$-GFP:B16) cells as well, IFN $\beta$ synthesized by $\mathrm{B} 16$ or $\mathrm{C} 57 \mathrm{Fb}$ cells inhibits the proliferation of tumor B16 cells (Fig. 3). However, the observed effect is more pronounced when the heterologous cells were co-cultured. Thus, at the 5th day of co-cultivation of B16 cells with $\mathrm{C} 57 \mathrm{Fb} / \mathrm{IFN} \beta$ or $\mathrm{C} 57 \mathrm{Fb} / \mathrm{IFN} \beta$-GFP the number of B16 cells decreased 5 and 11 fold, in comparison with co-culturing the homologous cells $-\mathrm{B} 16 / \mathrm{IFN} \beta$ :B16 and B16/IFN $\beta$-GFP:B16.



B16

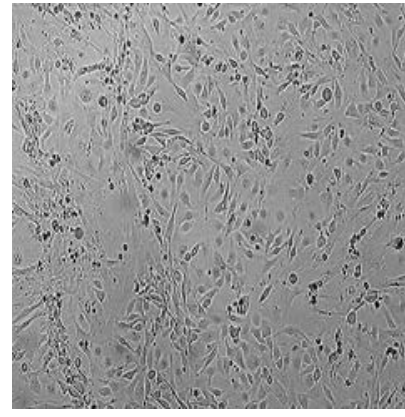

B16:C57Fb/IFN $\beta-G F P$

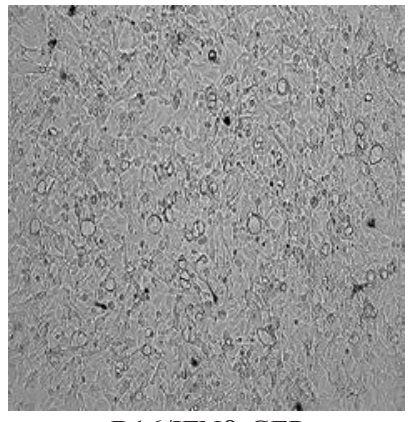

B16/IFN $\beta$-GFP

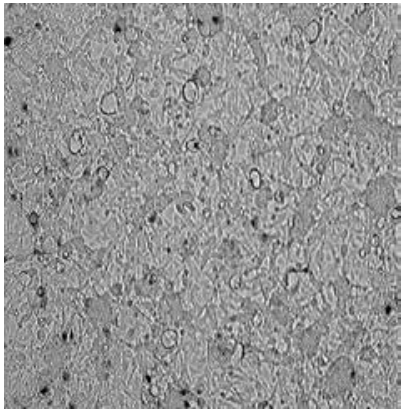

B16:B16/IFN $\beta-G F P$

Fig. 3. Antiproliferative influence of IFN $\beta$, synthesized by C57Fb or by tumor B16 cells, transduced with BVs, on melanoma cells (magnification $\times 10)$. 
BV carrying $I L-21$ no difference in the growth of tumor cells was observed (Fig. 2, column 7).

Analysis of proliferation of B16 and C57Fb cells (cultured alone), transduced with BV carrying Ifn $\beta$, revealed inhibition of the cell growth on the fifth day in comparison with all the control variants (Fig. 4, 5): $19.0 \% \mathrm{~B} 16 / \mathrm{IFN} \beta$ and $22.4 \% \mathrm{~B} 16 / \mathrm{IFN} \beta$-GFP; 49.8\% C57Fb/IFN $\beta$ and $33.3 \% \mathrm{C} 57 \mathrm{Fb} / \mathrm{IFN} \beta$-GFP. The number of $\mathrm{C} 57 \mathrm{Fb}$ cells in a "pure" control on the fifth day of culturing $-8.6 \times 10^{5}$ cells/well was taken for $100 \%$. The observed difference was statistically significant $(\mathrm{p}<0.001)$.

The growth of B16/FastMam cells was also significantly inhibited $(\mathrm{p}<0.05)$ in comparison with the growth of B16 cells in control (Fig. 4, column 4). The number of B16/IL21 cells does not differ from this index in the control variants. We also observed a significant reduction in the number of $\mathrm{C} 57 \mathrm{Fb} / \mathrm{GFP}$, $\mathrm{C} 57 \mathrm{Fb} / \mathrm{S} 18$ and $\mathrm{C} 57 \mathrm{Fb} /$ FastMam cells in comparison with a "pure" control ( $<<0.05, \mathrm{p}<0.01)$ (Fig. 5). Thus, $\mathrm{C} 57 \mathrm{Fb}$ cells showed increased responsiveness to the transduction with BVs as compared with B16 cells. As previously reported, this effect is probably associated with the induction of endogenous interferon or other cytokines in response to the baculovi-

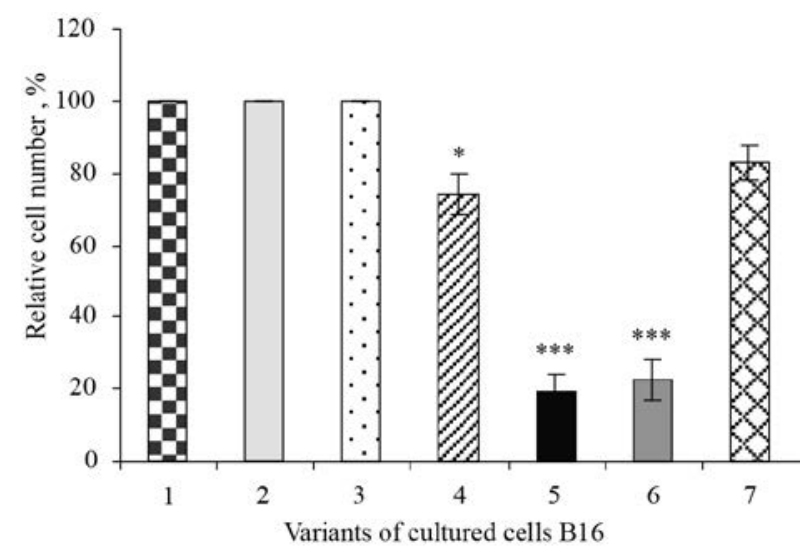

Fig. 4. The results of cell culture of melanoma B16, transduced with various BVs: 1 - control cells B16; 2 - B16/GFP; 3 B16/S18; 4 - B16/FastMam; 5 - B16/IFN $\beta$; 6 - B16/IFN $\beta$ GFP; $7-\mathrm{B} 16 / \mathrm{IL} 21$ The differences are significant at $* \mathrm{p}<0.05$; $* * * \mathrm{p}<0.001$ compared to the control. rus transduction of these cells and also depends on the expression of introduced transgenes. The number of $\mathrm{C} 57 \mathrm{Fb} / \mathrm{IL} 21$ cells was statistically significantly reduced $(\mathrm{p}<0.05)$ compared with the growth of $\mathrm{C} 57 \mathrm{Fb}$ cells alone. This is in line with previous findings, showing that IL-21 inhibits proliferation of $\mathrm{C} 57 \mathrm{Fb}$ as $\mathrm{B} 16$ cells which were co-cultured with $\mathrm{C} 57 \mathrm{Fb} / \mathrm{IL} 21$ (Fig. 1).

Noteworthy, C57Fb cells were more resistant to the anti-proliferative effect of IFN $\beta$ produced by these cells. It is known that the secreted IFN $\beta$ binds to specific receptors on the membrane and functions as a regulator of the cell proliferation through autocrine (affects the secreting cell itself), and paracrine (acts on neighboring cells and tissue) pathways [37]. Thus, IFN $\beta$ produced by the transduced $\mathrm{C} 57 \mathrm{Fb} /$ IFN $\beta, \quad$ C57Fb/IFN $\beta$-GFP, B16/IFN $\beta, \quad$ B16/IFN $\beta$ GFP cells inhibited their proliferation, and when cocultured with B16 cells it suppressed the melanoma cells proliferation.

Analysis of Ifn $\beta$ expression in C57Fb cells, transduced with BV carrying Ac-M-IFN $\beta$

To assess the kinetics of Ifn $\beta$ expression in $\mathrm{C} 57 \mathrm{Fb}$ cells, transduced with BV, q-PCR analysis was per-

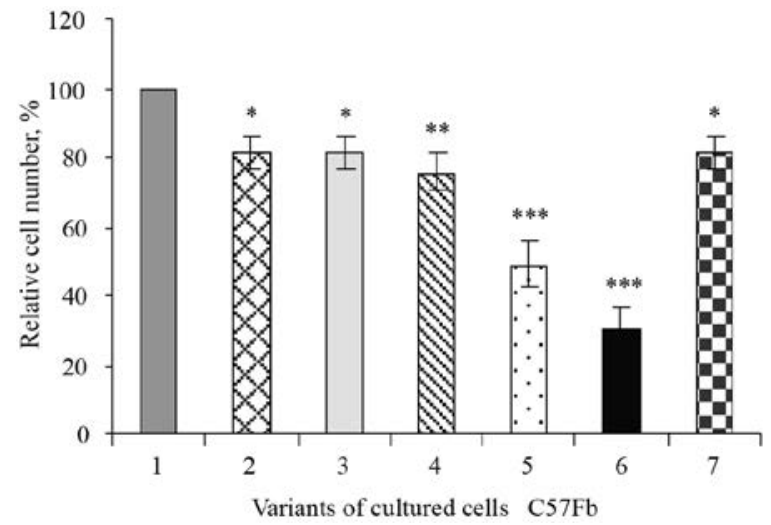

Fig. 5. The results of culturing mouse embryonic fibroblasts $\mathrm{C} 57 \mathrm{Fb}$ transduced with various BVs: 1 - control cells $\mathrm{C} 57 \mathrm{Fb}$; 2 - C57Fb/GFP; 3 - C57Fb/S18; 4 - C57Fb/FastMam; 5 $\mathrm{C} 57 \mathrm{Fb} / \mathrm{IFN} \beta ; 6$ - C57Fb/IFN $\beta$-GFP; 7 - C57Fb/IL21. The differences are significant at $* \mathrm{p}<0.05 ; * * \mathrm{p}<0.01 ; * * * \mathrm{p}<0.001$ compared to the control. 


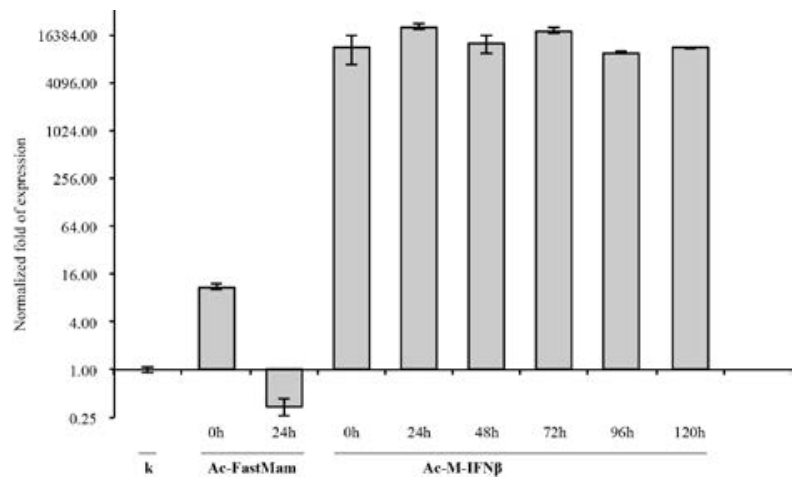

Fig. 6. Dynamics of the Ifn $\beta$ gene expression in embryonic fibroblasts $\mathrm{C} 57 \mathrm{Fb}$, transduced with $\mathrm{BVs}$. $\mathrm{x}$ - axis: time after transduction (h); $\mathrm{k}$ - control cells C57Fb; Ac-FastMam - C57Fb cells transduced with control BV; Ac-M-IFN $\beta-\mathrm{C} 57 \mathrm{Fb}$ cells transduced with BV containing the Ifn $\beta$ gene.

formed. It is known that BVs provide transient expression of transgenes in non-permissive mammalian cells in the absence of viral replication and a gradual loss of viral DNA upon cell division. As was shown earlier, the expression of GFP reporter protein may last for 30 days gradually decreasing, but stored in some single cells $[28,30]$. Using q-PCR, we showed that Ifn $\beta$ was expressed at a high level for 120 hours, substantially equal to that observed immediately after transduction (Fig. 6). Maximum value in our system was observed on the twentyfourth hour post transduction. The transduction of $\mathrm{C} 57 \mathrm{Fb}$ cells with the control baculovirus (AcFastMam) led to a minor increase in the synthesis of endogenous IFN $\beta$ that within 24 hours falls to a lower level than in cells without transduction (Fig. 6). These data are consistent with the previously reported and are associated with a response to introduction of $\mathrm{BV}$ by secreting cytokines including interferon [30]. Consequently, when B16 cells were cocultured with $\mathrm{C} 57 \mathrm{Fb} / \mathrm{IFN} \beta$ cells, IFN $\beta$ produced by MEF, provides a permanent inhibitory effect on the tumor cells for 120 hours.

\section{Conclusions}

We showed that IFN $\beta$, synthesized by C57Fb MEFs or by tumor B16 cells transduced with BVs, carrying the If $\beta$ gene, inhibited the proliferation of malig- nant mouse B16 melanoma cells in vitro. The effectiveness of inhibition of the B16 cells proliferation was higher when the heterologous cells were co-cultured. Hence, the interactions between MEFs and tumor cells contribute mostly to the inhibition of tumor cell proliferation.

We found that If $\beta$ was stably expressed in $\mathrm{C} 57 \mathrm{Fb}$ cells transduced with BV Ac-M-IFN $\beta$ for 120 hours. Noteworthy, $\mathrm{C} 57 \mathrm{Fb} / \mathrm{IFN} \beta$ cells were more resistant to the anti-proliferative effect of IFN $\beta$, than B16/IFN $\beta$ cells. The growth of B16 cells was inhibited upon cocultivating with $\mathrm{C} 57 \mathrm{Fb}$ cells transduced with BV carrying the $I L-21$ gene. Overall, we have demonstrated that MEFs can be used as potential anti-tumor vehicles delivering IFN $\beta$ or IL-21 to malignant melanoma. The preliminary findings of the present study support the further investigation of MEF-based gene therapy as a strategy for the treatment of melanoma $\mathrm{B} 16$ or other malignant tumors in vivo.

\section{REFERENCES}

1. Amara I, Touati W, Beaune P, de Waziers I. Mesenchymal stem cells as cellular vehicles for prodrug gene therapy against tumors. Biochimie. 2014;105:4-11.

2. Serakinci $N$, Fahrioglu $U$, Christensen R. Mesenchymal stem cells, cancer challenges and new directions. Eur $J$ Cancer. 2014;50(8):1522-30.

3. Cihova $M$, Altanerova $V$, Altaner $C$. Stem cell based cancer gene therapy. Mol Pharm. 2011;8(5):1480-7.

4. Mavroudi M, Zarogoulidis P, Porpodis K, Kioumis I, Lampaki S, Yarmus L, Malecki R, Zarogoulidis K, Malecki M. Stem cells' guided gene therapy of cancer: New frontier in personalized and targeted therapy. $J$ Cancer Res Ther (Manch). 2014;2(1):22-33.

5. Haniffa $M A$, Wang XN, Holtick $U$, Rae M, Isaacs JD, Dickinson AM, Hilkens CM, Collin MP. Adult human fibroblasts are potent immunoregulatory cells and functionally equivalent to mesenchymal stem cells. J Immunol. 2007;179(3): 1595-604.

6. Bhattacharya N. Fetal cell/tissue therapy in adult disease: a new horizon in regenerative medicine. Clin Exp Obstet Gynecol. 2004;31(3):167-73.

7. Sun H, Gulbagci NT, Taneja R. Analysis of growth properties and cell cycle regulation using mouse embryonic fibroblast cells. Methods Mol Biol. 2007;383:311-9.

8. Amit M, Shariki C, Margulets V, Itskovitz-Eldor J. Feeder layer- and serum-free culture of human embryonic stem cells. Biol Reprod. 2004;70(3):837-45. 
9. De Buys Roessingh AS, Hohlfeld J, Scaletta C, Hirt-Burri N, Gerber S, Hohlfeld P, Gebbers JO, Applegate LA. Development, characterization, and use of a fetal skin cell bank for tissue engineering in wound healing. Cell Transplant. 2006;15(8-9):823-34.

10. Saeed H, Taipaleenmäki H, Aldahmash AM, Abdallah BM, Kassem M. Mouse embryonic fibroblasts (MEF) exhibit a similar but not identical phenotype to bone marrow stromal stem cells (BMSC). Stem Cell Rev. 2012;8(2):318-28.

11. Yusuf B, Gopurappilly R, Dadheech N, Gupta S, Bhonde R, $P a l R$. Embryonic fibroblasts represent a connecting link between mesenchymal and embryonic stem cells. Dev Growth Differ. 2013;55(3):330-40.

12. Haniffa MA, Collin MP, Buckley CD, Dazzi F. Mesenchymal stem cells: the fibroblasts' new clothes? Haematologica. 2009;94(2):258-63. Review.

13. Lysy PA, Smets F, Sibille $C$, Najimi M, Sokal EM. Human skin fibroblasts: From mesodermal to hepatocyte-like differentiation. Hepatology. 2007;46(5):1574-85.

14. Goodbourn S, Didcock L, Randall RE. Interferons: cell signalling, immune modulation, antiviral response and virus countermeasures. J Gen Virol. 2000;81(Pt 10):2341-64.

15. Kaynor C, Xin M, Wakefield J, Barsoum J, Qin XQ. Direct evidence that IFN-beta functions as a tumor-suppressor protein. J Interferon Cytokine Res. 2002;22(11):1089-98.

16. Studeny M, Marini FC, Dembinski JL, Zompetta C, Cabreira-Hansen M, Bekele BN, Champlin RE, Andreeff $M$. Mesenchymal stem cells: potential precursors for tumor stroma and targeted-delivery vehicles for anticancer agents. J Natl Cancer Inst. 2004;96(21):1593-603.

17. Zhang F, Lu W, Dong Z. Tumor-infiltrating macrophages are involved in suppressing growth and metastasis of human prostate cancer cells by INF-beta gene therapy in nude mice. Clin Cancer Res. 2002;8(9):2942-51.

18. Ren C, Kumar S, Chanda D, Kallman L, Chen J, Mountz JD, Ponnazhagan S. Cancer gene therapy using mesenchymal stem cells expressing interferon-beta in a mouse prostate cancer lung metastasis model. Gene Ther. 2008;15(21):1446-53.

19. Ling X, Marini F, Konopleva M, Schober W, Shi Y, Burks J, Clise-Dwyer K, Wang R, Zhang W, Yuan X, Lu H, Caldwell L, Andreeff $M$. Mesenchimal stem cells overexpressing IFN- $\beta$ inhibit breast cancer growth and metastases though Stat3 signaling in a syngeneic tumor model. Cancer Microenviron. 2010; 3(1):83-95.

20. Skak K, Kragh M, Hausman D, Smyth MJ, Sivakumar PV. Interleukin 21: combination strategies for cancer therapy. Nat Rev Drug Discov. 2008;7(3):231-40.

21. Spolski R, Leonard WJ. Interleukin-21: a double-edged sword with therapeutic potential. Nat Rev Drug Discov. 2014;13(5):379-95.

22. Zhang Y, Wang J, Ren M, Li M, Chen D, Chen J, Shi F, Wang $X$, Dou J. Gene therapy of ovarian cancer using IL- 21-secreting human umbilical cord mesenchymal stem cells in nude mice. J Ovarian Res. 2014;7:8.

23. Frederiksen KS, Lundsgaard D, Freeman JA, Hughes SD, Holm TL, Skrumsager BK, Petri A, Hansen LT, McArthur GA, Davis ID, Skak K. IL-21 induces in vivo immune activation of $\mathrm{NK}$ cells and $\mathrm{CD} 8(+) \mathrm{T}$ cells in patients with metastatic melanoma and renal cell carcinoma. Cancer Immunol Immunother. 2008;57(10):1439-49.

24. Airenne KJ, Hu YC, Kost TA, Smith RH, Kotin RM, Ono C, Matsuura Y, Wang S, Ylä-Herttuala S. Baculovirus: an insect-derived vector for diverse gene transfer applications. Mol Ther. 2013;21(4):739-49.

25. Anopriyenko OV, Vagyna IN, Zaharuk OA, Strokovska LI, Solomko OP. Baculovirus vectors Ac-Cmv-Gfp, Ac-M-Gfp and Ac-Ifn-Gfp for effective gene transfer to the mammalian cells. Visn Ukr Tov Genet Sel. 2010; 8(1):3-9.

26. Hogan B, Beddington R, Costantini F, Lacy E. Manipulating the Mouse Embryo: a Laboratory Manual. Woodbury, USA: Cold Spring Harbor Lab Press. 1994; 497 p.

27. King LA, Possee RD. The baculovirus expression system. A laboratory guide. London: Chapmann and Hall, 1992; 220 p.

28. Vagyna IN, Anopriyenko OV, Zaharuk OA, Gorchev VF, Strokovska LI, Solomko AP. Efficient gene delivery into mammalian cells by baculovirus vector in vitro. Biopolym Cell. 2008; 24(6):508-12.

29. Chen GY, Shiah HC, Su HJ, Chen CY, Chuang YJ, Lo WH, Huang JL, Chuang CK, Hwang SM, Hu YC. Baculovirus transduction of mesenchymal stem cells triggers the tolllike receptor 3 pathway. J Virol. 2009;83(20):10548-56.

30. Chuang CK, Wong TH, Hwang SM, Chang YH, Chen GY, Chiu YC, Huang SF, Hu YC. Baculovirus transduction of mesenchymal stem cells: in vitro responses and in vivo immune responses after cell transplantation. Mol Ther. 2009;17(5):889-96.

31. Wang GX, Zhan YA, Hu HL, Wang Y, Fu B. Mesenchymal stem cells modified to express interferon- $\beta$ inhibit the growth of prostate cancer in a mouse model. J Int Med Res. 2012;40(1):317-27.

32. Dembinski JL, Wilson SM, Spaeth EL, Studeny M, Zompetta $C$, Samudio I, Roby K, Andreeff M, Marini FC. Tumor stroma engraftment of gene-modified mesenchymal stem cells as anti-tumor therapy against ovarian cancer. Cytotherapy. 2013;15(1):20-32.

33. Klopp AH, Gupta A, Spaeth E, Andreeff M, Marini F 3rd. Concise review: Dissecting a discrepancy in the literature: do mesenchymal stem cells support or suppress tumor growth? Stem Cells. 2011;29(1):11-9.

34. Flaberg E, Markasz L, Petranyi G, Stuber G, Dicso F, Alchihabi N, Oláh È, Csizy I, Józsa T, Andrén O, Johansson JE, Andersson SO, Klein G, Szekely L. High-throughput live-cell imaging reveals differential inhibition of tumor cell proliferation by human fibroblasts. Int $J$ Cancer. 2011; 128(12):2793-802. 
35. Flaberg E, Guven H, Savchenko A, Pavlova T, Kashuba V, Szekely L, Klein $G$. The architecture of fibroblast monolayers of different origin differentially influences tumor cell growth. Int J Cancer. 2012;131(10):2274-83.

36. Alkasalias T, Flaberg E, Kashuba V, Alexeyenko A, Pavlova T, Savchenko A, Szekely L, Klein G, Guven H. Inhibition of tumor cell proliferation and motility by fibroblasts is both contact and soluble factor dependent. Proc Natl Acad Sci U S A. 2014;111(48):17188-93.

37. Parker BS, Rautela J, Hertzog PJ. Antitumour actions of interferons: implications for cancer therapy. Nat Rev Cancer. 2016;16(3):131-44.

Ембріональні фібробласти миші, які експресують IFN $\beta$ або IL-21, інгібують проліферацію клітин меланоми in vitro

I. М. Вагіна, О. А. Захарук, Л. І. Строковська, Ю. В. Вагін, В. І. Кашуба

Мета. Вивчення впливу ембріональних фібробластів миші $(\mathrm{C} 57 \mathrm{Fb})$, трансдукованих бакуловірусними векторами (БВ), що містять гени мишачого Ifn $\beta$ або IL-21 людини, на виживаність і проліферацію злоякісних клітин меланоми миші (B16) in vitro. Методи. Трансдукція клітин, конструювання БВ, виділення РНК, кількісна ПЛР. Результати. Показано, що до антипроліферативного ефекту IFN $\beta$ виявилися чутливими всі досліджувані клітини як нормальні C57Fb, так і пухлинні B16; максимальну чутливість мали клітини В16, які швидко діляться. БВ забезпечували стабільну експресію гена Ifn $\beta$ на рівні мРНК протягом 5 діб в клітинах C57Fb/IFN $\beta$. Проліферація клітин В16 пригнічувалася при сумісному культивуванні з $\mathrm{C} 57 \mathrm{Fb} /$ IFN $\beta$ або C57Fb/IL21 клітинами. Висновки. IFN $\beta$ i IL-21, синтезовані ембріональними фібробластами С57Fb, трансдукованими БВ з генами Ifn $\beta$ або IL-21 інгібували проліферацію клітин В16 при їх сумісному культивуванні in vitro.
К л юч о в і с л о в а: ембріональні фібробласти, клітини меланоми, інтерферон $\beta$ (IFN $\beta$ ), інтерлейкін-21 (IL-21), бакуловірусні вектори, трансдукція.

Эмбриональные фибробласты мыши, экспрессирующие IFN $\beta$ или $I L-21$, ингибируют пролиферацию клеток меланомы in vitro

И. Н. Вагина, Е. А. Захарук, Л. И. Строковская, Ю. В. Вагин, В. И. Кашуба

Цель. Изучение влияния эмбриональных фибробластов мыши (C57Fb), трансдуцированных бакуловирусными векторами (БВ), содержащими гены мышиного Ifn $\beta$ или IL-21 человека, на выживаемость и пролиферацию злокачественных клеток меланомы мыши (B16) in vitro. Методы. Трансдукция клеток, конструирование БВ, выделение РНК, количественная ПЦР. Результаты. Показано, что к антипролиферативному эффекту IFN $\beta$ оказались чувствительными все исследуемые клетки как нормальные $\mathrm{C} 57 \mathrm{Fb}$, так и опухолевые B16; максимальной чувствительностью обладали быстро делящиеся клетки В16. БВ обеспечивали стабильную экспрессию гена Ifn $\beta$ на уровне мРНК в течение 5 суток в клетках $\mathrm{C} 57 \mathrm{Fb}$ / IFN $\beta$. Пролиферация клеток В16 подавлялась при со-культивировании с C57Fb/IFN $\beta$ или C57Fb/IL21 клетками. Выводы. IFN $\beta$ и IL-21, синтезируемые мышиными эмбриональными фибробластами, трансдуцированными БВ с генами If $\beta$ или $I L-21$ ингибировали пролиферацию клеток меланомы В16 in vitro.

Кл юч е в ы е сл о в а: эмбриональные фибробласты, клетки меланомы, интерферон $\beta$ (IFN $\beta$ ), интерлейкин-21 (IL-21), бакуловирусные векторы, трансдукция.

Received 04.06.2016 